\title{
MODERN APPROACHES FOR THE STUDY OF $s$-TRIAZINE HERBICIDE BIOREMEDIATION IN AGRICULTURAL SOILS
}

\author{
Marcela Hernández ${ }^{1,2}$, Verónica Morgante ${ }^{1}$, Cecilia Flores ${ }^{1}$, Patricio Villalobos ${ }^{1}$, \\ Myriam González ${ }^{1}$, Pola Miralles ${ }^{1}$, Alejandro Dinamarca ${ }^{1,3}$ and Michael Seeger ${ }^{1}$
}

${ }^{1}$ Laboratorio de Microbiología Molecular y Biotecnología Ambiental, Departamento de Química \& Millennium Nucleus of Microbial Ecology and Environmental Microbiology and Biotechnology EMBA, Universidad Técnica Federico Santa María, Av. España 1680,

Valparaíso, Chile. Corresponding author: michael.seeger@usm.cl

${ }^{2}$ Programa Doctorado en Ciencias de Recursos Naturales, Universidad de La Frontera,

Temuco, Chile.

${ }^{3}$ Laboratorio de Biotecnología Microbiana, Facultad de Farmacia, Universidad de

Valparaíso, Valparaíso, Chile.

\section{Enfoques modernos para el estudio de la biorremediación de herbicidas $s$-triazinas en suelos agrícolas}

Keywords: $s$-triazine, simazine, biodegradation, bioremediation, herbicide.

\begin{abstract}
The extensive use of $s$-triazine herbicides in diverse countries causes environmental and health concern. Simazine and atrazine are $s$-triazines widely used in agriculture and forestry. Although, natural dissipation of $s$-triazines in soils by physicochemical processes has been described, the main mechanism for their removal is biological degradation by microorganisms. Bioremediation is a successful strategy for the removal of $s$-triazines in soil. For bioaugmentation processes, $s$-triazine-degrading bacteria are required, which isolation from agricultural soils was described in this report. Studies of $s$-triazine adsorption and leaching in soil are useful to determine the bioavailability of these herbicides. The detection of $s$-triazine-degrading catabolic activity by most-probable-number (MPN) and the reduction of the respiration indicator 2,3,5-triphenyl-2H-tetrazolium chloride (TTC) were presented. The relative abundances of $s$-triazine catabolic genes in soil were analyzed by the MPNPCR technique. Culture-independent molecular methods such as FISH, T-RFLP and clone libraries are useful to study the effects of herbicide application and bioaugmentation on soil microbial communities and their dynamics. These experimental methods allow the design of biotechnological strategies for the clean-up of $s$-triazine contaminated soils.
\end{abstract}


Palabras claves: $s$-triazina, simazina, biodegradación, biorremediación, herbicida.

\section{RESUMEN}

El empleo masivo de herbicidas $s$-triazinas en diversos países ha causado preocupación ambiental y de salud. Simazina y atrazina son $s$-triazinas ampliamente utilizados en la agricultura y en predios forestales. La disipación natural de $s$-triazinas en suelos puede ocurrir por procesos físicoquímicos. Sin embargo, el principal mecanismo de remoción de estos herbicidas es la degradación mediada por microorganismos. La biorremediación es una estrategia eficiente para la remoción de $s$-triazinas del suelo. Para establecer procesos de bioaumentación, se requieren bacterias degradadoras de $s$-triazinas, cuyo aislamiento desde suelos agrícolas se describió en esta revisión. Estudios de adsorción y lixiviación de $s$-triazinas en suelos permiten determinar la biodisponibilidad de estos herbicidas. La actividad catabólica de microorganismos degradadores de simazina en suelo puede ser cuantificada por el método número más probable (NMP) y reducción del indicador de respiración cloruro de 2,3,5-trifenil-2H-tetrazolio (TTC). La abundancia relativa de genes catabólicos de $s$-triazinas en suelo fue analizada mediante la técnica NMP-PCR. Ténicas moleculares cultivo independiente, tales como FISH, T-RFLP y librerías de clones, son útiles para estudiar los efectos de la aplicación de herbicidas y de la bioaumentación sobre la estructura de las comunidades microbianas del suelo y su dinámica. Los métodos experimentales descritos en esta revisión permiten el diseño de estrategias biotecnológicas eficientes para la recuperación de suelos contaminados con $s$-triazinas.

\section{INTRODUCTION}

$s$-Triazine herbicides, such as simazine and atrazine, have been used extensively for control of leaf and grassy weeds (Radosevich et al., 1995). Due to the growing agricultural production in the world, large amounts of these herbicides have been applied. These agrochemicals, used primarily as pre- and post-emergent herbicides, interfere in the photosynthetic electron transport chain in susceptible plants by binding to the quinonebinding protein in photosystem II (Strong et al., 2002). The mobility of $s$-triazine in soil has contributed to the contamination of surface- and groundwater in several countries (Mandelbaum et al., 1995; Radosevich et al., 1995). Frequently, s-triazine herbicides have been detected exceeding the maximum pesticide acceptable levels in drinking water of Europe $\left(0.1 \mu \mathrm{g} \mathrm{l}^{-1}\right)$ and USA $\left(3.0 \mu \mathrm{g} \mathrm{l}^{-1}\right)$ (Mandelbaum et al., 1995; Rousseaux et al., 2001).

In Chile, cultivation areas have been increased $70 \%$ between 1997 and 2007
(Instituto Nacional de Estadísticas, Chile, 2007. Censos Agropecuarios 1997 - 2007. www.ine.cl). Atrazine and simazine are the $s$-triazines herbicides most used in Chile, with an annual application of 181 and 169 tons, respectively (Servicio Agrícola Ganadero, 2004. Declaración de ventas de plaguicidas de uso agrícola. Ministerio de Agricultura. Santiago, Chile). Simazine is applied in vineyards, avocado, apple and maize plantations as well as in pine and eucalyptus plantations (Cooman et al., 2005). Continuous application of $s$-triazines in Chilean soils is of increasing concern due to their potential contamination of surfaceand groundwater. However, only few reports describe $s$-triazine contamination in Chile. In soils simazine may leach to $90 \mathrm{~cm}$ depth depending of weather conditions and soil properties (Alister et al., 2005). Atrazine was detected in Chillán river at concentrations that are toxic for Daphnia spp. (Cooman et al., 2005). s-Triazine 
maximum contaminant levels for drinking water have not yet been established in Chile (Norma Chilena para Agua Potable, NCh 409/1. Of. 2005; Instituto Nacional de Normalización, Chile, www3.inn.cl). Simazine degradation in soil occurs predominantly by biological processes (Gebendinger and Radosevich, 1998; Newcombe and Crowley, 1999). For the design of herbicide bioremediation processes in contaminated soils, the isolation of native bacteria and the characterization of their $s$-triazine degradation potential are required. Diverse microorganisms able to degrade these herbicides have been isolated (Mandelbaum et al., 1995; Struthers et al., 1998; Topp et al., 2000a, 2000b; Hernández et al., 2008a; Hernández et al., 2008b). Pseudomonas sp. ADP has become the model strain for $s$-triazine biodegradation studies. This bacterial strain is able to use atrazine as the sole nitrogen source and its atrazine catabolic pathway has been extensively characterized (Martínez et al., 2001). The enzymes of the upper pathway, which are responsible for the conversion of atrazine to cyanuric acid, are encoded by the $a t z \mathrm{~A}, a t z \mathrm{~B}$ and $a t z \mathrm{C}$ genes. The lower pathway mineralizes cyanuric acid and is encoded by the atzDEF operon (Martínez et al., 2001). The herbicide simazine is also degraded by these catabolic enzymes (Fig. 1).

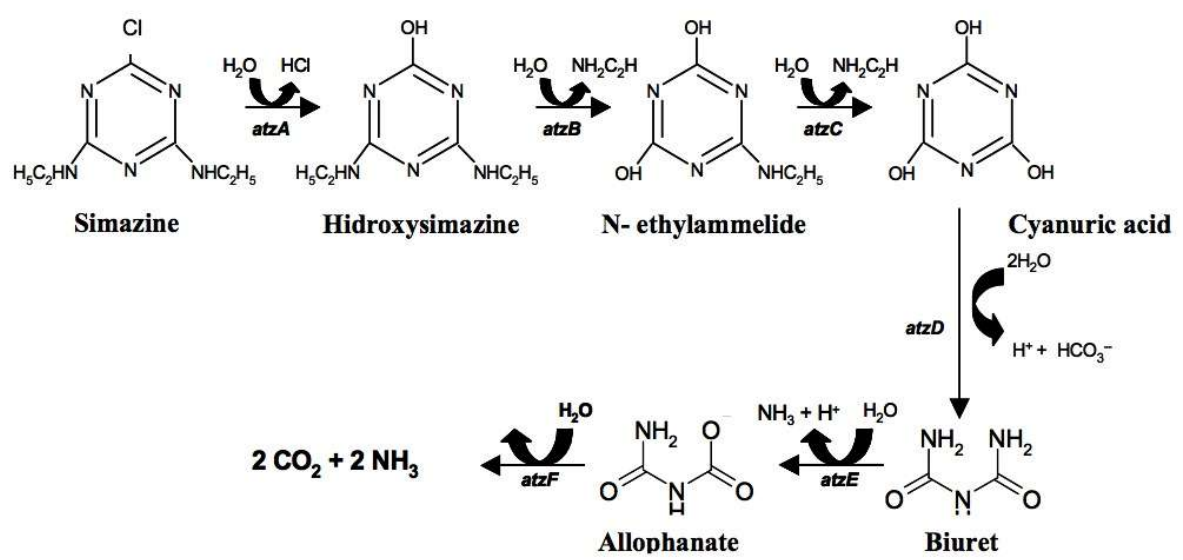

Figure 1: The simazine catabolic pathways. The atz genes encoding the metabolic enzymes are indicated.

Figura 1: Vías catabólicas de simazina. Se indican los genes atz que codifican las enzimas metabólicas. 
In this review, the isolation and characterization of $s$-triazine-degrading bacteria were reported. Studies on $s$-triazine retention and bioavailability in soil were presented. Modern methods for the analysis of microbial $s$-triazine catabolic activities and catabolic genes of soils were presented as a powerful combination of culturedependent and culture-independent techniques for laboratory, microcosm and field-scale studies. Finally, microbial ecology methods for the study of the structure and the dynamics of soil bacterial communities were reviewed.

\section{BACTERIAL DEGRADATION OF $s$-TRIAZINES}

Bioremediation employs microorganisms to degrade pollutants in the environment. Gram- negative and Gram-positive bacteria, predominantly Pseudomonas, Arthrobacter, Pseudaminobacter and Nocardiodes strains, capable to degrade $s$-triazine herbicides have been described (Yanze-Kontchou and Gschwind, 1994; Mandelbaum et al., 1995; Rousseaux et al., 2001; Topp et al., 2001; Strong et al., 2002).

To isolate microorganisms able to degrade $s$-triazines, we sampled agricultural soils from avocado and persimmon tree plantations annually treated with simazine in central Chile (Hernández et al., 2008b). Isolation was made by enrichment procedures in minimal medium using simazine as sole nitrogen source (Hernández et al., 2008a). Diverse strains able to degrade and use simazine as the sole nitrogen source for gowth were isolated from these soils. Some of these bacteria were characterized by sequencing $16 \mathrm{~S}$ rRNA genes and identified as species of Pseudomonas, Rodococcus, Stenotrophomonas and Arthrobacter. The simazine degradation potential of these bacterial strains was studied by resting cells assays. A novel $s$-triazine-degrading Pseudomonas strain was further characterized (Hernández et al., 2008a). These microorganisms are potential biocatalysts for bioremediation processes to remove $s$-triazines from polluted environments.

\section{SOIL CHARACTERIZATION}

\section{Soil properties and $s$-triazine retention}

Several factors determine the persistence of herbicides in soil (Novak, 1999). Soil physical and chemical properties such as texture, organic matter content as well as the $\mathrm{pH}$ strongly influence herbicide persistence. In addition, chemical properties of the herbicide such as solubility, vapor pressure, and the susceptibility to chemical or microbial degradation determine the environmental stability of the compound. Climatic variables, mainly moisture and temperature, are also relevant factors. However, microbial abundance and metabolic activity of soil microorganisms play a central role on herbicide fate in soil (Newcombe and Crowley, 1999). Retention and mobility of a pesticide in soil are determined by sorption processes, which are governed by physical-chemical properties of the soils and the pesticides (Spark and Swift, 2002). Sorption interactions of pesticides in the soil matrix may involve the mineral and/or organic components (Li et al., 2003). For soils with high organic matter levels ( $>5 \%$ ), pesticide retention has been associated with the binding to organic matter (Jenks et al., 1998). In soils with low organic matter content, pesticide adsorption depends on active components of the inorganic fraction, predominantly the clay. It has been postulated that an increase in the clay content decreases the mobility of the pesticide (Cox et al., 2000). Adsorption isotherms are commonly used to determine the herbicide affinity to soil and are often described by Freundlich- or Langmuir-type models (Calvet et al., 1989). Some studies describe the retention of $s$-triazines herbicides by soil constituents. Recently, simazine adsorption behavior was studied in 
agricultural soils of Aconcagua valley, central Chile (Flores et al., 2008). Soil organic matter and clay minerals are main sorbents for $s$-triazines (García-Valcárcel and Tadeo, 1999; Flores et al., 2008). In conclusion, physicochemical characteristics of the herbicide, the active surface of the minerals and the organic content of soils as well as the amount of herbicide applied are important parameters for understanding the dynamics of $s$-triazine herbicides in the environment. To protect surface- and groundwater from pesticide contamination, and to ameliorate their impact, broad knowledge is required concerning their sorption-desorption processes in the environment.

\section{Microbiological and molecular analysis of soils}

To establish bioremediation processes that remove $s$-triazines, the detection of active indigenous microbial communities able to degrade these herbicides is required. Recently, an interesting method for the detection and enumeration of MPN of $s$ triazine-degrading microorganisms in soil has been described (Dinamarca et al., 2007). This method is based on the ability of bacteria to use a $s$-triazine as sole nitrogen source. The metabolic activity of microorganisms is detected by the reduction of 2,3,5-triphenyl-2H-tetrazolium chloride into a colored formazan product.

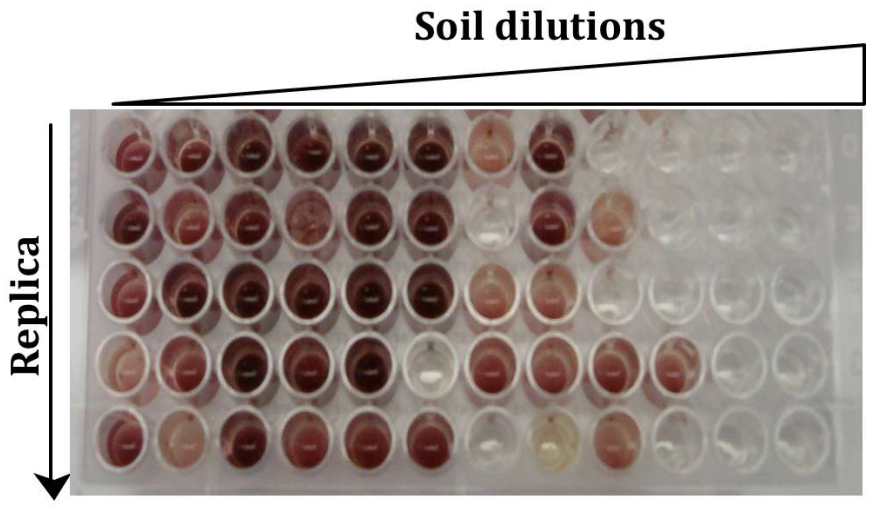

Figure 2: Detection of $s$-triazine degrading activities in soils by MPN-TTC method. Ten-fold serial dilutions of soil sample were prepared and 5 wells of a microtiter plate were inoculated. At the end of incubation, TTC was added $(0.01 \%$ final concentration) and the microtiter plate was incubated at $30^{\circ} \mathrm{C}$ during $4 \mathrm{~h}$. A positive reaction is determined by visualization of the color change by the production of formazan (red color).

Figura 2: Detección de actividad degradadora de $s$-triazina en suelos mediante el método NMPTTC. Se prepararon diluciones seriadas (1/10) de muestras de suelo y se inocularon en cinco pocillos de una microplaca. Al final de la incubación, se adicionó TTC (concentración final de 0,01\%) y se incubó la microplaca a $30^{\circ} \mathrm{C}$ durante 4 horas. El cambio de color por la producción de formazán (color rojo) indica una reacción positiva. 
The simazine-degrading activities of microorganisms in an avocado plantation soil from central Chile are shown in Figure 2 . The microbial catabolic activities in soils can be attributed to the previous history of simazine treatment (Rousseaux et al., 2001; Ralebitso et al., 2002, Morán et al., 2006).

The relative abundances of $s$-triazine catabolic genes in soil can be analyzed by a MPN-PCR technique. The detection of $a t z A$ gene in DNA extracted directly from this soil is illustrated in Figure 3.

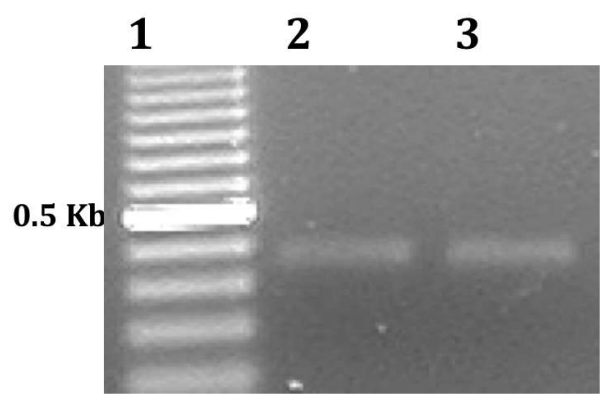

Figure 3. Amplification of catabolic atzA gene from soils treated with simazine. Molecular mass markers (line 1), freshly applied herbicide soil (line 2), soil four weeks after herbicide application (line 3).

Figura 3. Amplificación del gen catabólico atzA desde muestras de suelos tratados con simazina. Marcadores de masa molecular (línea 1), suelo recién tratado con el herbicida (línea 2), suelo tratado con el herbicida hace 4 semanas (línea 3).

The PCR-amplification of atz $A$ in agricultural soils was performed according to the protocols and primers previously described (de Souza et al., 1998). The presence of the atzA gene in soils is in accordance with the detection of catabolic activities of indigenous simazine-degrading microorganisms. The $s$-triazine catabolic activities quantified by the MPN-TTC method and the catabolic genes determined by the MPN-PCR technique correlates with simazine removal from these soils.

\section{BIOREMEDIATION STUDIES}

Bioremediation is an effective technology for the clean-up of polluted environments. This biotechnology has several advantages compared to the physicochemical treatments: lower operational costs, in situ application, permanent elimination of the residue, and minimum disturbance of the treated site (Ralebisto et al., 2002; Philp and Atlas, 2005; Navia and Seeger, 2006). The most efficient methods for transforming a contaminant into a less-harmful end product are biostimulation and bioaugmentation. Biostimulation involves treating the contaminated soils to increase the pollutant bioavailability, or adding a nutritional supplement or co-substrate to increase the population of contaminant-degrading indigenous bacteria (McTavish, 2001). Bioaugmentation involves the inoculation of contaminated soils or water with specific microbial strains or consortia to improve the biodegradation capacity of the system for a specific organic pollutant (Philp and Atlas, 2005).

Successful bioaugmentation of $s$-triazinepolluted soils has been described (YanzeKontchou and Gschwind, 1994, Alvey and Crowley, 1996, Newcombe and Crowley, 1999, Morgante et al., 2008). For bioaugmentation strategies, bacterial strain selection, inoculum size and inoculation system are important parameters. Bacterial strain selection is critical for bioremediation strategies. The strains used for bioremediation should posses exceptional degrading capacities and important growth rates (Philp and Atlas, 2005; Navia and Seeger, 2006). Therefore, the adaptability of the inoculated strain to the soil and the long term survival of the microorganism are desirable properties. Higher bioremediation efficiency was obtained by inoculating native 
strains (Rousseaux et al., 2002). Secondly, to increase the biodegradation rate, the native strain has to be inoculated to the polluted site at high densities. For soil bioremediation a higher inoculum size is required than for bioaugmentation of aquatic ecosystems. A high inoculum size allows overcoming competition with native bacteria, predation by protozoa and bacteriophage and lower pollutant bioavailability due to sorption mechanisms in soil (Philp and Atlas, 2005). For atrazine bioremediation in soils, different inoculum sizes have been tested (Topp, 2001; Rousseaux et al., 2002). Finally, the inoculation system is an essential factor in bioaugmentation. Inoculation of cells immobilized in alginate matrices, or other polymeric materials, is a strategy of increasing importance. For example, alginate allows passage of nutrients and excretion products, protects bacteria from predators and nutrient stress and preserves viability of the organisms (Newcombe and Crowley, 1999). Bioaugmentation with repeated inoculations could be useful for increasing bioremediation efficiency. Repeated applications of the strain overcome longterm survival problems (Newcombe and Crowley, 1999). Recently, a successful bioaugmentation strategy for agricultural soil using the native simazine-degrading bacterium Pseudomonas sp. strain MHP41 was reported (Morgante et al., 2008). After bioaugmentation with strain MHP41, simazine catabolic activities were increased and herbicide removal was enhanced.

\section{ANALYSIS OF SOIL MICROBIAL COMMUNITIES BY MOLECULAR METHODS}

Microorganisms play key functions in soil and are able to adapt to changing environmental conditions. Thus, variations in bacterial populations and activities may serve as excellent indicators of changes in soil health (Torsvik and Overas, 2002). Most microbes in environmental samples can not be cultured in laboratory media, which are biased for the growth of specific microorganisms (Torsvik et al., 2002). Molecular biology techniques and microbial culture-independent approaches are increasingly employed for the study of the microbial ecology in complex environments (Alfreider et al., 1996; Muyzer and Smalla, 1998; Osborn, et al., 2000; Nogales et al., 2001). The $16 \mathrm{~S}$ rRNA gene sequence is important for the analysis of microbial diversity and is a relevant marker for studying the phylogeny of bacteria (Fig. 4).

To date, most studies quantify the depletion of the contaminant or monitor cultivable microorganisms or their catabolic activities in polluted soils. Only few reports describe the dynamics of microbial communities throughout the biodegradation process (Piutti et al., 2003; Moreno et al., 2007). The knowledge of the microbial communities inhabiting $s$-triazine contaminated soils and their response to bioaugmentation strategies is useful for the identification of the microorganisms that are adapted to these compounds and are involved in their degradation. Changes in the bacterial community structure in soil by pesticides application have been observed (Engelen et al., 1998; El Fantroussi et al., 1999). The structure of the microbial community in an atrazine-contaminated soil changed in response to soil organic amendments (Martin-Laurent et al., 2004) and carbon and nitrogen source availability (Rhine et al., 2003). Microbial community structure of $s$-triazine treated soil has been studied by FISH (Barra Caracciolo et al., 2005). Specific groups of bacteria such as $\alpha-, \beta$ -

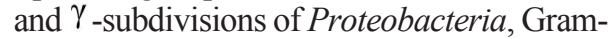
positive bacteria of high GC DNA content and Planctomycetes were detected. The presence of $s$-triazines affected the bacterial community structure. 


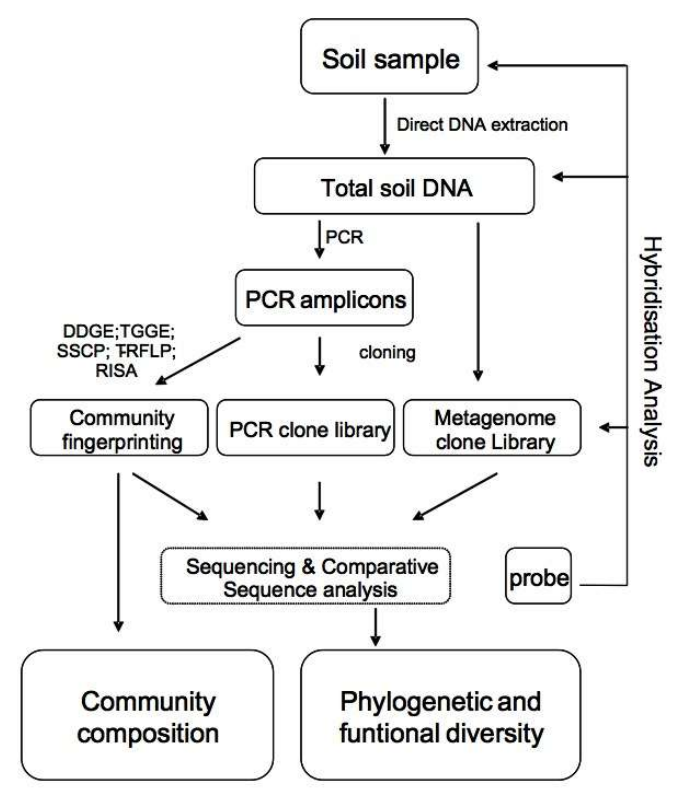

Figure 4. Culture-independent molecular methods for the analysis of microbial communities. PCR: polymerase chain reaction; DGGE: denaturant gradient gel electrophoresis; TGGE: temperature gradient gel electrophoresis; SSCP single strand conformation polymorphism; T-RFLP: terminal restriction fragment length polymorphism; RISA: ribosomal intergenic spacer analysis.

Figura 4. Métodos moleculares cultivo independientes para el análisis de comunidades microbianas. PCR: reacción en cadena de la polimerasa; DGGE: electroforesis en gel con gradiente desnaturalizante; TGGE: electroforesis en gel con gradiente de temperatura; SSCP: polimorfismo de la conformación de cadena simple de ADN; T-RFLP: polimorfismo de longitud de fragmentos de restricción terminales; RISA: análisis del espaciador intergénico ribosomal.

The bacterial community structure of a pesticide-contaminated site and the changes induced in the community structure during bioremediation approaches has been recently described (Paul et al., 2006). The microbial community of this pesticide-contaminated soil was mainly constituted by Proteobacteria and Actinomycetes. Bioaugmentation enhanced pollutant degradation. However, T-RFLP analysis revealed non-significant changes in bacterial community structure during the bioremediation process. In Chilean agricultural soils, we evaluated the capability of native soil microbiota and bioaugmentation strategies on simazine biodegradation by microcosm experiments. The 16S rRNA gene pool amplified from the soil genomic library was cloned and FISH and T-RFLP was performed to analyze changes in soil microbial community structure due to simazine amendment and bioaugmentation strategies. Our results showed that the native soil microbiota was 
able to degrade simazine. However, the addition of a native strain enhanced simazine-degrading activities and was essential for increasing the attenuation of simazine in soil. Sequencing of representative clones of soil bacteria showed that the microbial community structure was mainly constituted by Proteobacteria, Actinomycetes, Acidobacteria and Planctomycetes. Microbial community analysis by T-RFLP revealed that simazine application and bioaugmentation promotes changes in the structure of soil microbial communities, while FISH indicates variations in some specifics bacterial groups.

\section{CONCLUSIONS}

In this review, the basis of bioremediation of herbicides in agricultural soils was analyzed. Diverse simazine-degrading strains isolated from Chilean agricultural soils were characterized. The MPN-TTC method was used for the estimation of the $s$-triazine-degrading activities in soil. Catabolic genes for $s$-triazine degradation were detected in soil by MPN-PCR. Bacterial community adapted to the herbicide application and with simazine catabolic capabilities are present in Chilean agricultural soils. Culture-independent molecular methods such as FISH, T-RFLP and clone libraries were used to understand the effects of herbicide application and bioaugmentation on soil microbial communities. The isolated $s$-triazinedegrading microorganisms are novel biocatalysts that were used for the development of bioaugmentation strategies.

\section{ACKNOWLEDGMENT}

MS acknowledges financial support of Millennium Nucleus EMBA P04/007-F, USM 130522 and ICA4-CT-2002-10011 (European Union) grants. AD and PM acknowledge FONDECYT 3050052 and USM CIDEP 70714 grants, respectively. $\mathrm{MH}$ gratefully acknowledges CONICY T fellowship. PV and VM gratefully acknowledge MECESUP-UCV-0206 fellowships.

\section{REFERENCES}

ALFREIDER, A., PERNTHALER, J., AMANN, R., SATTLER, B., GLÖCKNER, F.-O., WILLE, A., AND PSENNER R. 1996. Community analysis of the bacterial assemblages in the winter cover and pelagic layers of a high mountain lake by in situ hybridization. Appl. Environ. Microbiol. 62:2138-2144.

ALISTER C., LÓPEZ R., AND KOGAN, M. 2005. Simazine dynamics in a vineyard soil at Casablanca valley, Chile. Pest Manage. Sci. 61: 10831088.

ALVEY, S., AND CROWLEY, D. E. 1996. Survival and activity of an atrazinemineralizating bacterial consortium in rhizosphere soil. Environ. Sci. Technol. 30: 1596-1603.

BARRA CARACCIOLO, A., GRENNI, P., CICCOLI, R., DI LANDA, G., AND CREMISINI, C. 2005. Simazine biodegradation in soil: analysis of bacterial community structure by in situ hybridization. Pest. Manag. Sci. 61: 863-9.

CALVET, R. 1989. Adsorption of organic chemicals in soils. Environ. Health Pespect. 83: 145-177.

COOMAN, K., DEBELS, P., GAJARDO, M., URRUTIA, R., AND BARRA, R. 2005. Use of Daphnia spp. for the ecotoxicological assessment of water quality in an agricultural watershed in South-Central Chile. Arch. Environ. Contam. Toxicol. 48: 191200.

COX, L., CELIS, R., HERMOSÍN, M. C., AND CORNEJO, J. 2000. Natural soil colloids to retard simazine and 2,4-D leaching in soil. J. Agric. Food Chem. 48: 93-99 
DE SOUZA, M. L., SEFFERNICK, J., MARTINEZ, B., SADOWSKY, M. J., AND WACKETT, L. P. 1998. The atrazine catabolism genes $a t z A B C$ are widespread and highly conserved. J. Bacteriol. 180: 19511954.

DINAMARCA, M. A., CERECEDABALIC, F., FADIC, X., AND SEEGER, M. 2007. Analysis of $s-$ triazine-degrading microbial communities in soils using mostprobable-number enumeration and tetrazolium-salt detection. Int. Microbiol. 10: 209-215.

EL FANTROUSSI, S., VERSCHUERE, L., VERSTRAETE, W., AND TOP, E. M. 1999. Effect of phenylurea herbicides on soil microbial communities estimated by analysis of 16S rRNA gene fingerprints and community-level physiological profiles. Appl. Environ. Microbiol. 65: 982-988.

ENGELEN, B., MEINKEN, K., VON WINTZINGERODE, F., HEUER, H., MALKOMES, H. P., AND BACKHAUS, H. 1998. Monitoring impact of a pesticide treatment on bacterial soil communities by metabolic and genetic fingerprinting in addition to conventional testing procedures. Appl. Environ. Microbiol. 64: 2814-2821.

FLORES, M., MORGANTE, V., GONZÁLEZ, M., NAVIA, R., AND SEEGER, M. 2008. Adsortion studies of herbicide simazine in agricultural soils of the Aconcagua valley, central Chile. Submitted.

GARCÍA-VALCÁRCEL, A., AND TADEO, J. 1999. Influence of soil moisture on sorption and degradation of hexazinone and simazine in soil. J. Agric. Food Chem. 47: 3895-3900.
HERNÁNDEZ, M., VILLALOBOS, P., MORGANTE, V., GONZÁLEZ, M., REIFF, C, MOORE, E., AND SEEGER, M. 2008a. Isolation and characterization of a novel simazinedegrading bacterium from agricultural soil of central Chile, Pseudomonas sp. MHP41. FEMS Microbiol. Lett. In press.

HERNÁNDEZ, M., MORGANTE, V., ÁVILA, M., VILLALOBOS, P., MIRALLES, P., GONZÁLEZ, M., AND SEEGER, M. 2008b. Novel $s$ triazine-degrading bacteria isolated from agricultural soils of central Chile for herbicide bioremediation. Electron. J. Biotechnol. In press. JENKS, B. M., ROETH, F. W., MARTIN, A. R., AND MCCALLISTER, D. L. 1998. Influence of surface and subsurface soil properties on atrazine sorption and degradation. Weed Sci. 46: 132-138.

LI, H., SHENG, G., TEPPEN, B. J., JOHNSTON, C. T., AND BOYD, S. A. 2003. Sorption and desorption of pesticides by clay minerals and humic acid-clay complexes. Soil Sci. Soc. Am. J. 67: 122-131.

MANDELBAUM, R. T., ALLAN, D. L., AND WACKETT, L. P. 1995. Isolation and characterization of a Pseudomonas sp. that mineralizes the $s$-triazine herbicide atrazine. Appl. Environ. Microbiol. 61: 1451-1457.

MARTIN-LAURENT, F., CORNET, L., R A N J ARD, L., LÓ PEZGUTIÉRREZ, J. C., PHILIPPOT, L., SCHWARTZ, C., CHAUSSOD, R., CATROUX, G., AND SOULAS, G. 2004. Estimation of atrazinedegrading genetic potential and activity in three French agricultural soils. FEMS Microbiol. Ecol. 48: 425-435. 
MARTÍNEZ, B., TOMKINS, J., WACKETT, L. P., WING, R., AND SADOWSKY, M. J. 2001. Complete nucleotide sequence and organization of the atrazine catabolic plasmid pADP-1 from Pseudomonas sp. strain ADP. J. Bacteriol. 183: 5684-5697.

MCTAVISH, H. 2001. Microbes and methods for remediation. United States Patent, Number WO0155409. USA.

MORÁN, A.C., MULler, A., MANZANO, M., and GONZÁLEZ, B. 2006. Simazine treatment history determines a significant herbicide degradation potential in soils that is not improved by bioaugmentation with Pseudomonas sp. ADP. J. Appl. Microbiol. 101: 26-35.

MORENO J., ALIAGA, A., NAVARRO, S., HERNÁNDEZ, T., AND GARCÍA, C. 2007. Effects of atrazine on microbial activity in semiarid soil. Appl. Soil Ecol. 35: 120-127. MORGANTE, V., MIRALLES, P., FLORES, M., GONZÁLEZ, M., VÁZQUEZ, M., AND SEEGER, M. 2008. Bioaugmentation of simazinecontaminated soil with free and immobilized cells of Pseudomonas sp. strain MHP41. Submitted. MUYZER, G., AND SMALLA, K. 1998. Application of denaturant gradient gel electrophoresis (DGGE) and temperature gradient gel electrophoresis in microbial ecology. Antonie van Leeuwenhoek 73:127141.

NAVIA, R. AND SEEGER, M. 2006. Biorremediación de suelos contaminados con compuestos orgánicos persistentes (COPs), Editorial Universidad de La Frontera, Temuco. Chile.

NEWCOMBE, D. A., AND CROWLEY, D. E. 1999. Bioremediation of atrazine-contaminated soil by repeated applications of atrazinedegrading bacteria. Appl. Microbiol. Biotechnol. 51: 877-82.
NOGALES, B., MOORE, E. R., LLOBETBROSSA, E., ROSSELLO-MORA, R., AMANN, R., AND TIMMIS, K. N. 2001. Combined use of $16 \mathrm{~S}$ ribosomal DNA and $16 \mathrm{~S}$ rRNA to study the bacterial community of polychlorinated biphenyl-polluted soil. Appl. Environ. Microbiol. 67: 1874-1884.

NOVAK, J. M. 1999. Soil factors influencing atrazine sorption: Implications on fate. Environ. Toxicol. Chem. 18; 1663-1667.

OSBORN, A. M., MOORE, E. R., AND TIMMIS, K. N. 2000. An evaluation of terminal-restriction fragment length polymorphism (T-RFLP) analysis for the study of microbial community structure and dynamics. Environ. Microbiol. 2: 39-50.

PAUL D., PANDEY, G., MEIER, C., VAN DER MEER, J. R., AND JAIN, R. K. 2006. Bacterial community structure of a pesticide-contaminated site and assessment of changes induced in community structure during bioremediation. FEMS Microbiol. Ecol. 57: 116-127.

PHILP J. M., AND ATLAS, R. M. 2005. Bioremediation of contaminated soils and aquifers. In: Bioremediation: Applied microbial solutions for realworld environmental cleanup (Atlas, R. M., and Philp, J Eds.). pp. 138220. ASM Press. Washington, USA.

PIUTTI S., SEMON, E., LANDRY, D., HARTMANN, A., DOUSSET, S., LICHTFOUSE, E., TOPP, E., SOULAS, G., AND MARTINLAURENT, F. 2003. Isolation and characterisation of Nocardioides sp. $\mathrm{SP} 12$, an atrazine-degrading bacterial strain possessing the gene $t r z N$ from bulk- and maize rhizosphere soil. FEMS Microbiol. Lett. 221: 111-117. 
RADOSEVICH, M., TRIANA, S. J., HAO, Y. L., AND TUOVINEN, O. H. 1995. Degradation and mineralization of atrazine by a soil bacterial isolate. Appl. Environ. Microbiol. 61: 297302.

RALEBITSO, T. K., SENIOR, E., AND VAN VERSEVELD, H. W. 2002. Microbial aspects of atrazine degradation in natural environments. Biodegradation 13: 11-19.

RHINE, E.D., FUHRMANN, J.J. AND RADOSEVICH M. 2003. Microbial community responses to atrazine exposure and nutrient availability: Linking degradation capacity to community structure. Microb. Ecol. 46:145-160

ROUSSEAUX, S., HARTMANN, A., AND SOULAS, G. 2001. Isolation and characterization of new Gramnegative and Gram-positive atrazine degrading bacteria from different French soils. FEMS Microbiol. Ecol. 36: $211-222$.

ROUSSEAUX S., HATMANN, A., LAGACHEIRE, B., PIUTTI, S., ANDREAUX, F., AND SOULAS, G. 2002. Inoculation of an atrazinedegrading strain, Chelatobacter heintzii Cit1, in four different soils: effects of different inoculum densities. Chemosphere 51: 596-576.

SPARK, K.M., AND SWIFT, R.S. 2002. Effect of soil composition and dissolved organic matter on pesticide sorption. Sci. Total Environ. 298: $147-161$.

STRONG, L. C., ROSENDHAL, C., JOHNSON, G., SADOWSKY, M. J., AND WACKETT, L. P. 2002. Arthrobacter aurescens TC1 metabolizes diverse $s$-triazines ring compounds. Appl. Environ. Microbiol. 68: 5973-5980.
STRUTHERS, J. K., JAYACHANDRAN, K., and MOORMAN, T. B. 1998. Biodegradation of atrazine by Agrobacterium radiobacter $\mathrm{J} 14 \mathrm{a}$ and use of this strain in bioremediation of contaminated soil. Appl. Environ. Microbiol. 64: 3368-3375.

TOPP, E., ZHU, H., NOUR, S. M., HOUOT, S., LEWIS, M., AND CUPPELS, D. 2000a. Characterization of an a tra z i n e - d e g r a d i n g Pseudaminobacter $\mathrm{sp}$. isolated from Canadian and French agricultural soils. Appl. Environ. Microbiol. 66: 2773-2782.

TOPP, E., W. M. MULBRY, W. M., ZHU, H., NOUR, S. M, AND CUPPELS, D. 2000b. Characterization of $s$ triazine herbicide metabolism by a Nocardioides sp. isolated from agricultural soils. Appl. Environ. Microbiol. 66: 3134-3141.

TOPP, E. 2001. A comparison of three atrazine-degrading bacteria for soil bioremediation. Biol. Fert. Soils 33: 529-534.

TORSVIK, V., OVREAS, L., AND THINGSTAD, T. F. 2002. Prokaryotic diversity magnitude dynamics, and controlling factors. Science 296: 1064-1066.

TORSVIK, V., AND OVREAS, L. 2002. Microbial diversity and function in soil: from gene to ecosystem. Curr. Opin. Microbiol. 5: 240-245. YANZE-KONTCHOU, C., AND GS C HW IN D, N. 1994. Mineralization of the herbicide atrazine as a carbon source by a Pseudomonas strain. Appl. Environ. Microbiol. 60: 4297-4302. 